\title{
Rethinking a Timely Response of Human Resources to Global Signals: A Case of Organizational Reflexes
}

\author{
Sigitas Vaitkevicius ${ }^{1}$, Palmira Papsiene ${ }^{2}$, Jura Vladas Vaitkevicius ${ }^{1}$ \\ ${ }^{1}$ Vytautas Magnus University \\ K. Donelaicio st. 58, LT- 44248 Kaunas, Lithuania \\ E-mail.sigitas.vaitkevicius@gmail.com; v.vaitkevicius@splius.lt \\ ${ }^{2}$ Vytautas Magnus University Agriculture Academy, Faculty of Bioeconomy Development \\ Studentu st. 11, LT-53361 Akademija, Kauno dstr., Lithuania \\ E-mail.palmira.papsiene@gmail.com \\ cross $^{\text {ref }}$ http://dx.doi.org/10.5755/j01.ee.32.1.24199
}

\begin{abstract}
The general idea of this paper is to present a model that could explain which characteristics of the human reflex arc are inherited by the system of an organization's human resources when they respond to a signal incoming from the global environment. The possibility of inheritance in an organization is discussed in the theories associated with Sociobiology, Biological view in Strategic Management, Reductionism, Microfoundations, and the advanced experience of inheriting neural activity that can be found in Experimental Neuropsychology. Similarity and consolidation of differences incoming from these theories allowed for the theoretical development of a Reflexes model of an organization's human resources response to the signals from the global environment. The analysis of organizational response to the signals incoming from the global environment and its reaction to the system's activity have shown that an organization operates very similarly to the human reflex arc. This insight allowed recognizing the human nervous system's structure as a constituent in an organization's decision-making system. In this paper, the model of the biological nature of the organization behavior is presented. It explains how an organization forms its reflexive competitive response to the signals incoming from the global environment.
\end{abstract}

Keywords: Reflexes; Human Resource; Organizational Response; Global Environment; Reflexes Model.

\section{Introduction}

Analysis of human resources management discourse (Sadowska \& Lulek, 2020; Jashary \& Kutllovci, 2020; Elrehail et all., 2020; Rodjam et all., 2020; Han et all., 2019; Barrena-Martinez et all., 2019; Shah, 2019; Gunnigle et al., 2019; Chaudhary, 2019; Roscoe et all., 2019; Yang et all., 2019; Li et all., 2018; Vasantha \& Kennedy, 2017; Newman, 2016; Tang et all., 2015; Youndt et all., 1996) and review of organizational internationalization theory (Brymer et all., 2020; Andersson \& Sundermeier, 2019; Vahlne \& Bhatti, 2019; Suseno\& Pinnington, 2018; Alon et all., 2018; GodosDiez et all., 2018; Jankowska, Gotz, 2017; Chen et all., 2016; Kalvionyte \& Korsakiene, 2016; Fitzgerald \& Rowley, 2016; Babinska, 2013) enabled theoretical modeling of the system that explores the fundamentals of information reception incoming from the global environment in an organization. This finding has led to the development of a concept that describes the ability of a public-sector organization to respond to the tasks related to its internationalization.

In answering the question of how the response to the incoming signals from the global environment process works in an organization and why it inherits its biological features, theories were reviewed that discuss the biological nature of the organization. These theories - the biological organization theory (Milne, 1970; Morgan, 2006), and Biological view in Strategic Management (Davenport et al., 2007) - allowed one to establish the relation of the organization to its human nature, and also to highlight structural variables of organization interaction that reveal the principles of an organization functioning under the laws of human anatomy. The analysis of the theories of Sociobiology (Wilson, 1975), Reductionism (Udehn, 2002), Microfoundations (Barney \& Felin, 2013), and Experimental Neuropsychology (Dreher \& Tremblay, 2017; Allpsychologycareers, 2016) were an important grounding of the human reflex arc as a constituent of the organization response system. The latter theories permit the grounding of the human reflex arc's capability to explain how the organization develops its reflexes.

Analyzing the theoretical statements describing the processes that intermediate the management of human resources and internationalization, it has been noticed that, in the process of the reception of information from the global environment and during the formation of a response to it, hypothetically, an active role is played by human resources assessment and the organizational climate (Hu \& Zhao, 2020; Gokalp et all., 2020; Klinck \& Swanepoel, 2019; Walker et all., 2014; Pandey \& Chandel, 2013; Popa \& Demyen, 2012; Dadelo et all., 2012; Riego de Dios, 2020; Akbar et all., 2019; Gaviria-Rivera \& Zapata, 2019; Nasreen et all., 2019; Berberoglu, 2018; Phua, 2018; Polat \& Iskender, 2018; Naldoken \& Tengilimoglu, 2017; Pozveh \& Karimi, 2016). Studying the human resources assessment and the organizational climate in the case of internationalization, allowed for an insight as to the information incoming from the global environment. The effectiveness and influence of the penetration itself depend on the assessment of human resources. Rethinking an earlier research on the 
interdependence between organizational climate and the assessment of human resources has revealed that the assessment of human resources possibly has an impact on the organizational climate and can be used as a tool for management of its sensitiveness. It acts as the guiding system activating or deactivating the perception sensors that are naturally built in human resources and are responsible for acceptance or rejection of the incoming information.

The penetration analogy was selected because it describes not only the information's reception, but also enables an interpretation of a reception as a selective process that describes a free will of the organization. It is based on the philosophy of existentialism (Stanford Encyclopedia of Philosophy. Existentialism;

https://plato.stanford.edu/entries/existentialism/).

From the philosophy of existentialism, the concept of freedom is taken, which is used to describe a relation of the human and his/her surrounding world as a percept. The philosophy of existentialism emphasizes individual existence, freedom and choice, and it asserts that humans define their own meaning in life, and try to make rational decisions despite existing in an irrational universe. The same properties are described by G. Morgan (2006) in his book Images of Organization. For example, in Morgan (2006), an image of organization as an organism also describes an organization as a living unit and emphasizes the importance of the relationship between an organization and its environment. This is important as a description of the concept of an organization's freedom and choice.

The image of an organization as a brain emphasizes that an organization is capable of learning and that it depends on self-organization. This explains the rationality of an organization and its competence to define its own meaning. This point of view also can be extrapolated from the philosophy of existentialism as an analogy to the contraposition expressed by existentialists regarding human's materialization chosen by rationalists (Webber, 2011). Criticism of an organization's materialization from a biological point of view (Gavin, 2018; Arvey \& Zhang, 2015) also can unlock possibilities of knowing the organization as pertains to existential freedom. According to existentialism, freedom is what a human would be not as something formed due to natural or social necessity, but what one would "choose" himself/herself, would form himself/herself by his/her every action and act (Berdjaev, 2006).

In the case of an organization, and assessing it from a biological point of view (Gavin, 2018; Arvey \& Zhang, 2015; Davenport et al., 2007) that is close to G. Morgan's (2006) image of the organization as a brain, the organization also can "choose" itself and reshape itself. There is revealed a similarity of human resources management as a tool of selfformation, and the organizational climate is revealed as a reason of self-choosing in the analyzed context of human resources management and interaction of internationalization. Therefore, the basic problem of the research is what is the anatomy of an organization's information receiving process, and what simultaneous acting of human resource factors

\footnotetext{
1 Papšienè, Palmira; Vaitkevičius, Sigitas. Biological model of organization's communication with external environment // Drivers for progress in the global society: 3rd European interdisciplinary forum 2015 (EIF 2015), June 18-19, 2015,
}

determines the organization's reaction to an organization's internationalization?

Therefore, the main problem of the research is the discovery of the organization's sensorimotor, cognitive, and affective response functions that would allow increasing or decreasing sensitiveness of the enterprise to the signals incoming from the global environment.

The research examines the mechanism of human resources response to the incoming signals from the global environment and to the management stimuli, and based on the finding result develops the typology of an organization's sensorimotor, cognitive, and affective response functions.

The aim of this research was to develop a model that would reflect the biological characteristics of the organization's response to the signals incoming from the global environment.

The research methods - theoretical modeling based on development of analogy grounded by hermeneutical analysis of interdependence between the human reflex arc and the organization's response to the signals from the global environment.

The intention of the research:

Rethinking the reflexes model of the organization's HR communication with the external environment, it has been noticed that the same components, like human resources or organizational climate, can play different roles in the same organization. It is possible that the interaction between the organizational climate and the human resource management can be not only responsible for a motor-response that consists of a conditional and unconditional response, but also can act as a knowledge-development tool, which replicates the human brain activity. What if the organization can see, hear, feel, analyze, and decide as people do? The answer to this question became possible after Barney and Felin (2013) interpreted the Microfoundations theory. They draw the line between the constituent and the system, and explained to what extent the constituent is capable of explaining the system. This led to the presupposition that an organization can replicate human anatomy and use it to be self-organized.

The idea was to separate the layers of personal and organizational thinking by using the critical hermeneutic theory, and then to find out by what means the brain functions in the organization.

This paper is revised and updated version of the paper initially presented to the scientific community in the $3^{\text {rd }}$ European Interdisciplinary Forum 2015 (EIF) "Biological model of organization's communication with external environment"1.

\section{Literature Review}

\section{Theories Grounding the Biological Model}

Such theories as Sociobiology (Wilson, 1975), Biological view in Strategic Management (Davenport et al., 2007 Niman, 1994; Fos, 1994; Penrose, 1952), and Microfoundations (Barney \& Felin, 2013) explain how

Vilnius (Lithuania) / Editor Agota Giedrè Raišienè. Bologna : MEDIMOND, 2015. ISBN 9788875877262. p. 157-168. 
biologic qualities can be related to the decisions of a group. For example, the theories in the tradition of sociobiologism (Wilson, 1975) provide a good explanation for unreflective behavior of living organisms, animals and humans. Such theories can contribute to an explanation of individual and group behavior, which is driven by genes / biological programs, instincts, strong emotions, extreme or irrational forces (for example leaders and followers, mass behavior, and behavior in unusual or extreme situations) (Diefenbach, 2013). These theories say that part of a group of people's actions consists of unreflective behavior that needs no outside instructions and regulations because the action model is inside of the organism itself. This partially explains why some people can easily understand each other without initial instructions and succeed in the decision-making process at the business start-up. It is simply because they act under some kind of similar algorithm, which is common to group or organization members. Here we come to an important question: is it enough to link the organization to the human nature of its individuals?

The theory of Microfoundations (Barney \& Felin, 2013) answers this question. The possibility for an organization to inherit human qualities can be found in the study of Barney and Felin (2013), where they describe microfoundations as a concept. In their paper, to define microfoundations, they review the reductionist approach where they discuss the practice of analyzing a complex phenomenon in terms of its simple or fundamental constituents (Udehn, 2002). Barney and Felin (2013) clearly define the limits of the reductionist approach stating that "organizations and social systems are a function of the set of individuals contained within them. From a practical perspective, this means that we can understand organizations and their performance by carefully specifying the exact nature of these individuals-their personalities, abilities, and skills-and study organizational and social performance in a simple, additive fashion". The next important thing which authors explore and which is important for model development is their description of the microfoundations features. They argue: "but microfoundations are not solely about individuals. The problem with reducing everything to individuals [...] is that it ignores the interactions among them as well as the context of the organization itself (cf. Whetten, Felin, \& King, 2009). Individual interactions are not simply additive, but can take on complex forms and lead to surprising aggregate and emergent outcomes that are hard to predict based on knowledge of the constituent parts. Thus, reducing, or attempting to reduce, everything to individuals is only "micro" - not microfoundational. In other words, the foundations portion of microfoundations is important in that it places emphasis on the need to specifically understand the unique, interactional, and collective effects that are not only additive but also emergent."

This explanation on the one hand says that one system is not equal to another, which explains the nature of its behavior because the nature of the behavior itself is not equal to the achievement of the aim behaving in this way. It means that part of the system is important but not important enough for explaining the complete operation of the total system. This insight raised the question whether the system of such an organization can be considered as a uni-living system or is it just like a bunch of grapes growing or fastened together and which is recognized as grapes but not the grape alone. The Biological view in Strategic Management (Davenport et al., 2007) answers this question.

According to the Davenport et al. (2007), in the biological view, or living organism paradigm an organization is considered as a uni-minded living system, just like a human being, with a purpose of its own. // Uniminded systems have a choice, their parts do not - the organization is seen as being under the control of an executive function, and its parts have no choice - if parts should display choice, a conflict would arise.

The biological view when compared to the discussed theories takes its own unique place. It tightens the statements of previous theories by considering that a group, which is driven by the same quality of its members (sociobiology and reductionism) and being not the same as its part (microfoundations), can also be a uni-minded living system - which means that the organization operates like a human being. This leads to the statement that an organization as a human being may share the same qualities that are inherent in human nature.

From the perspective of our research, the limitation of already discussed theories is that they mostly are based on Mereology (Stanford Encyclopedia of Philosophy (2015. Jan.15). Mereology. Stanford Encyclopedia of Philosophy; http://plato.stanford.edu/entries/mereology/).

The limitation is that the mereology does not explain the possibility of the system (as a whole) to inherit the quality of its constituent (as a part). This theory only explains how and to what extent the system depends on its parts. In other words, mereology and the discussed theories explain why an organization consists of humans' actions according to human nature, but it does not explain the organizations' phenomenon of inheriting the qualities of a human like a brain or motor response. More clarity in this discussion is brought to light by the work, Experimental Neuropsychology (Ellis \& Young, 1995). In seeking for the answers, Experimental Neuropsychology concerned itself with organization management principles.

Experimental neuropsychology leads to the insight that if such qualities like cognition, attention, perception, and memory are inherited by the organization, possibly the motor function and the substitute of cortical structure can be inherited by the organization too.

This statement has been made not by following the basic principles of mereology, but, instead, by the applying the Phenomenological Hermeneutics (Vaitkevicius, 2013) as a tool that defines the thinking logic for construct development. The difference in applying of Phenomenological Hermeneutics is that the result of this comparison is not an exploration of the parts, which are essential for an organization's humanity, but also the discovery that an organization acts as a human being. It does this because the organization replicates the processes of human decisionmaking, and not because humans make decisions for it. In other words, this does not turn the organization into a human, but makes it act like humans do. This happens because such a way of acting is governed by human nature and, according to the theory of sociobiology, it is essential in the development of the natural environment for unreflective 
behavior of humans within an organization. This explains how an organization consisting of different people, becomes a uni-minded system where all of its human parts being selfsupporting by nature and by nature similar to the system as a whole coexist in harmony and operate simultaneously, and do not needlessly overlap each other. That is the true phenomenon of an organization which allows its growth from one person being the company, which fully replicates and is completely dependent on that one person's behavior, to the hundreds of thousands people, each of them replicating only a small part of their own behavior in order to create the more advanced algorithm of the cumulated natural human behavior. All of this definitely led to the statement that an organization inherits the qualities of the human being and that this makes it similar to human beings. Therefore, according to Mereology, the organization does not inherit physically from the human the brain itself, but, according to the Phenomenological Hermeneutics, it inherits the brain function. This statement grounds the organization's ability to inherit the motor function from human physiology.

Core Elements of a Model of an Organization's Communication with the External Environment

Due to this modelling, a system of environment communication with the organization is being studied as a latent variable that is operationalized by the cumulative interaction of three variables: assessment of human resources (Hu \& Zhao, 2020; Gokalp et all., 2020; Klinck \& Swanepoel, 2019; Walker et all., 2014; Pandey \& Chandel, 2013; Popa \& Demyen, 2012; Dadelo et all., 2012), organizational climate (Riego de Dios, 2020; Akbar et all., 2019; Gaviria-Rivera \& Zapata, 2019; Nasreen et all., 2019; Berberoglu, 2018; Phua, 2018; Polat \& Iskender, 2018; Naldoken \& Tengilimoglu, 2017; Pozveh \& Karimi, 2016) and organization's internationalization (Brymer et all., 2020; Andersson \& Sundermeier, 2019; Vahlne \& Bhatti, 2019; Suseno \& Pinnington, 2018; Alon et all., 2018; Godos-Diez et all., 2018; Jankowska \& Gotz, 2017; Chen et all., 2016; Kalvionyte \& Korsakiene, 2016; Fitzgerald \& Rowley, 2016; Babinska, 2013). Variables: assessment of human resources, and organizational climate were analyzed as individual factors. These factors function as an information mediator and as a cumulative factor which moderates a motive of information receiving in the context of human resources management; the third, the organization's internationalization was selected as a moderator. It transforms a signal from the environment into a stimulus of change.

Whereas human resources management and the organizational climate as a factor of an organization's adaptation to the changing environment are widely discussed in the literature (Riego de Dios, 2020; Akbar et all., 2019; Gaviria-Rivera \& Zapata, 2019; Nasreen et all., 2019; Berberoglu, 2018; Phua, 2018; Polat \& Iskender, 2018; Naldoken \& Tengilimoglu, 2017; Pozveh \& Karimi, 2016), thus, using the method of phenomenological hermeneutics (Vaitkevicius, 2013), there have been identified the features of its use for the purpose of organization's self-defense. This is why, human resources management and organizational climate in relation to the internationalization, can be discussed as a quality of the organization that allows it to secure its identity.
This approach allows to study an assessment of human resources and organizational climate as a barrier that has to be taken by information incoming from outside to the organization. It leads to the understanding that this additive part of the total organizational structure at the same time can act as a barrier for coming changes and as a system which separates the desired changes from the unwanted ones in the organization. The limitation of previous research is that assessment of human resources, the organization's climate, and internationalization were not yet analyzed jointly. The research prior to this time explored the fact that an organization communicates with its outer environment, and the way this is utilized: the internationalization (Brymer et all., 2020; Andersson \& Sundermeier, 2019; Vahlne \& Bhatti, 2019; Suseno \& Pinnington, 2018; Alon et all., 2018; Godos-Diez et all., 2018; Jankowska \& Gotz, 2017; Chen et all., 2016; Kalvionyte \& Korsakiene, 2016; Fitzgerald \& Rowley, 2016; Babinska, 2013) as a connectivity system; the organizational climate as a system that remains responsible for the functionality of the organization (Riego de Dios, 2020; Akbar et all., 2019; Gaviria-Rivera \& Zapata, 2019; Nasreen et all., 2019; Berberoglu, 2018; Phua, 2018; Polat \& Iskender, 2018; Naldoken \& Tengilimoglu, 2017; Pozveh \& Karimi, 2016); and the assessment of human resources. The assessment of human resources an organization uses as a tool for directing the personnel's efforts to achieve the organizational objectives during the communication process (Hu \& Zhao, 2020; Gokalp et all., 2020; Klinck \& Swanepoel, 2019; Walker et all., 2014; Pandey \& Chandel, 2013; Popa \& Demyen, 2012; Dadelo et all., 2012).The previous researchers sufficiently explored the features of the constructs discussed above, but they also revealed the need for a theoretical modeling of their content's compatibility by assessing how an organization's forms and perception of itself could be important for further study of the organization's functioning principles. This importance can be discussed from at least two perspectives.

The first perspective is that despite the different authors, there is no analysis of the influence of the assessment of human resources to the organizational climate in the context of an organization's internalization; however, each of these factors separately has been widely discussed and disputed in the literature.

The second perspective is that authors discussing each of these factors are taking the same common organization's model as a base. Therefore, it could be stated that all three factors substantially coexist in the same organization at the same time. Therefore, there should be a logically explained relation between them. Besides, while comparing all three constructs, internationalization is distinguished as an external factor, while the management of human resources together with the organizational climate is distinguished as an internal factor of the organization's development and identity that is inevitably intertwined with an external factor. These different philosophies can lead to the different causes of the nature of the interaction between the inner and outer factors. For example, existentialism would ground the interaction of inner and outer factors as becoming important from the perspective of an organization's internal need for change, while from the point of view of rationalism, their interaction would be seen as caused by an external impulse. 
All of this shows that the interaction between organizational climate, assessment of human resources, and internationalization, not discussed until now, can be interrelated and they can share the same purpose.

All three constructs used for modeling in the literature are pointed out as important for the development of the organization. They describe the directness of an organization's development (Seilius et al., 2006), its competitive potential (Kazlauskaite \& Buciuniene, 2008; Isoraite, 2011), and its ability to establish itself and survive during market evolution (Kersiene, 2008). A priori, all markets in which organizations are acting irrespective of an organization's type (business or non-business organizations) are developing. Markets differ only by the speed and scale of evolution. For example, the markets in which business subjects are acting have a tendency to develop more rapidly than the markets in which organizations warranting social security are acting. This is due to the different nature of organizations, which determines an organization's inertness and resistance to change.

The interrelation of market evolution and an organization creates a need for the modeling of an organization's communication with the external environment, and allows for the answering of such questions important to management science as: with help of what functional mechanism, an organization reacts to the signals sent by the environment; why organizations do not form a response to all signals sent by the environment; and if the organization's response can be treated as unconditional and conditional as regards to the process of how it responds, and finally if it can be equated to human unconditional and conditional reflexes.

\section{The Objective of an Organization's Communication with the External Environment, and the Distinguishing Features Describing its Identity}

The assessment of human resources as a tool of an organization's self-development is characterized by its active features. They describe the directness of the organization's evolution (Guest, 1987). This is because the assessment of its own structure accumulates indicators from the knowledge acquired. This knowledge serves as a reference point for achieved level assessment and exists as: a human's capability criterion in the organization, a direction for personal evolution, and as a target to be achieved. The assessment creates an achievement motive for the person. This motive being expressed as an achievement argument for an objective, acts as a direction tool for the person and helps him/her to separate the true decisions from the false ones in an organization. Therefore, the assessment can assist the person in choosing selectively what incoming information from the global environment to accept and what to reject in order to achieve the organization's greater competitiveness in the market. In a broader sense, an assessment, by directing the persons to build their competencies in a certain field, makes them more sensitive to the particular kind of incoming information and develops the selection criteria for it.

The nature of an organization's climate in the organization reveals itself through its structure. The organization's climate shows the balance in communication between the people. In some organizations, especially the smaller ones, where people know each other, the organization's climate will be characterized by viva voce communication. This will lead to less control of the information flow process and to the greater independence of the person who decides to accept or reject the incoming information from the global environment. In this case, the effectiveness of the decision will depend on the experience and the knowledge of the person who makes the decision.

In other organizations, the organization's climate will depend on the documented rules and the written instructions. They serve as the decision-making algorithm for the organization's personnel. Documented control is more often used in bigger organizations where it synchronizes the decisions and coordinates the actions of the personnel. It helps to standardize the routine processes including information acceptance and rejection; also, it reduces the number of mistakes in predicted situations and prevents the emergence of conflicts.

The level of internationalization is the ability to integrate an international, intercultural, or global dimension into the purpose, functions, and delivery of products or services. It shows how much information from the global environment the organization receives and to how much of it the organization has to respond. The level of internationalization also can be used as an indicator for the evaluation of the organization's sensitivity to the signals incoming from the global environment. This is because organizations having a higher level of internationalization are more sensitive to the signals incoming from the global environment. It is in their nature. Being close to the global markets, international organizations learn to identify a higher variety of the signals incoming from the global environment, whereas local organizations only react to these signals which affect and change local conditions.

Complex analysis of the assessment of human resources (Hu \& Zhao, 2020; Gokalp et all., 2020; Klinck \& Swanepoel, 2019; Walker et all., 2014; Pandey \& Chandel, 2013; Popa \& Demyen, 2012; Dadelo et all., 2012); organization's climate (Riego de Dios, 2020; Akbar et all., 2019; Gaviria-Rivera \& Zapata, 2019; Nasreen et all., 2019; Berberoglu, 2018; Phua, 2018; Polat \& Iskender, 2018; Naldoken \& Tengilimoglu, 2017; Pozveh \& Karimi, 2016); and internationalization ( Brymer et all., 2020; Andersson \& Sundermeier, 2019; Vahlne \& Bhatti, 2019; Suseno \& Pinnington, 2018; Alon et all., 2018; Godos-Diez et all., 2018; Jankowska \& Gotz, 2017; Chen et all., 2016; Kalvionyte \& Korsakiene, 2016; Fitzgerald \& Rowley, 2016; Babinska, 2013) showed an intentionality of interaction of human resource assessment and organizational climate, which is the response to the attempts of the global world to penetrate an organization's existence in order to change the perception of its being.

During the comparison, it was noticed that their interaction in accordance to internationalization is revealed not only as a complex identity, but also as a condition of the organization's resistance to the impact of the external environment. So, from the one side, this allows for an analysis of the ability of the organization to adapt to the changing environment; from the other side, it can be used for a description of the motive formation mechanism, which helps to resist and prevent influences from the environment. Therefore, looking from an organizational perspective, what creates the existential presupposition of the organization, at 
the same time creates a barrier for external factors that can distort the perception of organization's being.

\section{Method}

Analogue Model for the Study of the Biological Nature of HR Communication with the External Environment in an Organization

An organization is a sophisticated system consisting of many structural elements that individually have contact with the internal and external environment, and constantly act and actively respond to environmental changes. The ability to react to environmental changes distinguishes the organization from lifeless physical objects, stimulates the organization to retain its uniqueness, and creates a process within an organization's evolution: signal, reaction, and response. It is similar in the case of the human nervous system, where the brain consists of about 100 billion neurons and about 100 trillion synapses which are responsible for acceptance of the incoming signal, reaction to it and the response (Neuronal connections, 2007). In human nature, the reaction to the incoming signal and response to it predetermines the human physical activity, human mind and emotions. (Neuronal connections, 2007). In an organization, hypothetically it may predetermine its activity and the process of decision making.

To develop a hypothetical model which explains how organizations respond to the signals sent from the global environment, the operation of organizations has been studied under the conditions of the internationalized market. The results from this study have been compared to a model of the human nervous system's structure and activity, and have been assessed in perspective of the biological theory that states that every organization function as a living organism (Milne, 1970; Morgan, 2006). This model is presented in Figure 1.

The interrelation between organizational climate and human resource assessment has been rethought. As a result of earlier studies, the presupposition was made that hypothetically an organization intuitively manages its response to the information. This statement came from the perception that, the human resource assessment as a phenomenon in the organization hypothetically can play a role similar to the management of the organizational climate. The studied researches demonstrated the significant impact of the human resource assessment on the organizational climate. They also explored whether the human resource assessment can tune the organizational climate and make it more or less sensitive to the environment and incoming signals from it.

The internalization in the model was used as a factor to explain the mechanism by which, the organization receives the information incoming from the global environment. According to this source, the flow of the information from the global environment depends on the level of the internationalization changes. It was found that the greater the internationalization, the more the information received from the global environment. This means that hypothetically the internationalization in the company can operate as a signal receiver which is responsible for the management of the global information flow.
The modeling of interdependence between the organizational climate, the human resource assessment and internationalization has led to the development of several models that explain how interdependence between organizational climate and human resources assessment becomes a barrier for incoming information from the global environment and how it supports the incoming information flow.

To explain the developed models, answers were looked for in different disciplines: human resource management, organizational sociology, psychology, strategic management, management etc. These disciplines have already developed the models that mostly explain how an organization operates and what processes are taking place in it. Some of them described the behavior of the actors during these processes, but none of them discussed the nature and intention of interdependence between the organizational climate and human resource assessment. The exploration of this has led to the development of a model of a system of global environmental communication which reflects the biological nature of the organization, and explains how a signal transferred from the global environment to an organization and passing the organizational climate becomes an organization's competitive response to the global environment.

The Methods and Philosophy of Research. Because such cases have not been researched yet, it was decided to rethink the findings from the research already done and, by using theoretical modeling based on development of analogy, which is grounded by hermeneutical analysis of interdependence between the human reflex arc and an organization's response to the signals from the global environment, to develop a model that could explain the organizational climate's and human resource's assessment role in that process. For this modeling, the concept of metaphysical materialism as a philosophical tradition has been selected (Hudson, 2001).

\section{Result}

Reflexes model of an organization's HR response to the signals from the global environment. The principles of an organization's reactivity system operation (TARGET (T)) could be explained with the help of the human reflex arc (SOURCE (S)) (see Table 1). It was an attempt to link the knowledge of anatomy that allows for the recognition of the human nervous system structure and the knowledge of epistemology to the findings from the human resource management survey. This created a possibility to compare the principles of the human nervous system and an organization's operation (see Figure 1 and Table 1).

During the comparison, essential elements of the nervous system - sensors (d), effectors (C), spinal nerves (B, D) and brain as a system (Swanson \& Bota, 2010) (see A) - were extrapolated to the model of a system of global environment communication with the organization (see Picture 1). As a result of the extrapolation, a model of a system of global environment communication was developed.

The model shows that the signal sent by the global environment can reach the organization because of internationalization. The internationalization as an example is responsible for the scanning of the global environment, for 
learning from the global environment, for networking, for the use of new technologies etc. These and other features of the internationalization makes it important for the model.

While developing the model, there was no objective to explain all possible connections to the global environment; therefore, attention was focused on the explanation of the role of the organizational climate $\left(\mathrm{c}^{*}\right)$.

The organizational climate $\left(c^{*}\right)$ plays at least two very important roles in this model. First, it supports the unconditional response of human resources (HR) $\left(P^{*} 1\right)$. Second, it develops the barrier for unwanted information that may distract the strategic course of the organization.

The purpose of this comparative analysis was to find the possible similarities between the human reflex arc (S) and the organization's communication with the external environment, but not to relate them completely. The supposition in this research is that the human anatomy is not the anatomy of the organization, but because humans create the organizations, so, hypothetically, the organization is about human nature, and therefore, despite some differences, it can be of the same design as human anatomy. This can explain why the interdependence between the organizational climate $\left(\mathrm{c}^{*}\right)$ and human resource assessment $\left(b^{*}\right)$ reflects the memorization of the signal and reflex formation $(\mathrm{B}, \mathrm{b}, \mathrm{e})$ in the human reflex arc (S), and creates the barrier of the internal environment $\left(\mathrm{B}^{*}\right)$, which is responsible for admittance of the wanted and filtering out the unwanted information that comes from the global environment.

Another feature that makes the barrier of the internal environment $\left(\mathrm{B}^{*}\right)$ comparable to the spinal cord $(\mathrm{B})$ is that the organizational climate not only separates the incoming information, but also together with instructions from human resource assessment ( $\left.b^{*}\right)$ helps to decide to respond to it conditionally or unconditionally. In this case, it acts as a moderator $\left(\mathrm{e}^{*}\right)$, which is responsible for strengthening of the incoming signal through the sensors, for response through the effector $\left(\mathrm{C}^{*}\right)$, which can be any particular action of an organization that creates the competitive response to the global environment, and for a request sent as information to the management level of human resources ( $\left.f^{*}\right)$. The typical example of such a request would be the personnel request for an internship to learn a new technological process, which in the future could become a necessity for work in this position (a task for human resource assessment $\left(b^{*}\right)$ ), and which may result in the company's interest in the use of it to strengthen its competitive advantage (indirect information $\left(g^{*}\right)$ ).

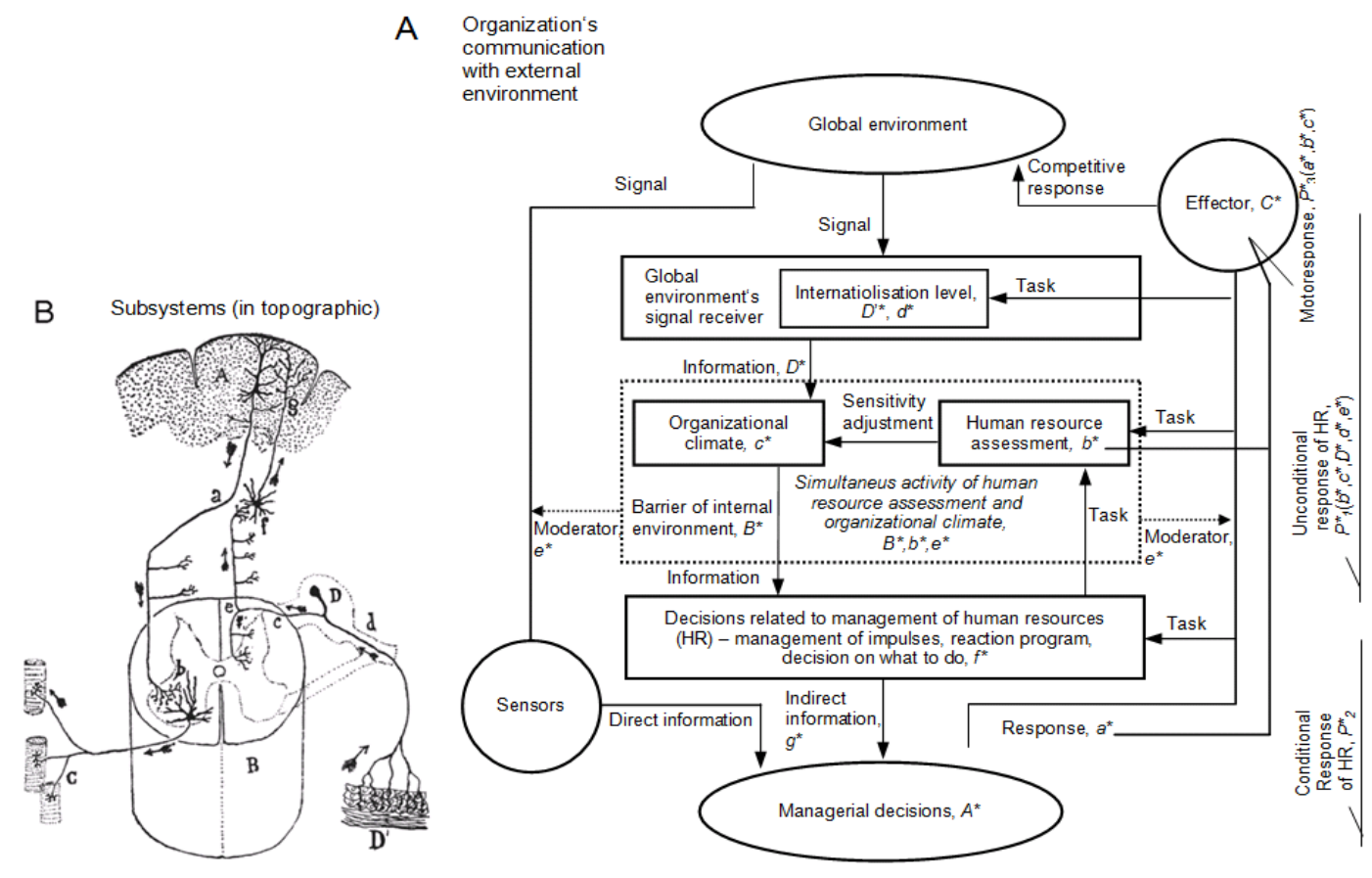

Figure 1. Reflexes model of organization's HR communication with external environment ${ }^{2}$ (similarity modeling presented in Table 1)

The human resource assessment's $\left(b^{*}\right)$ role in this model is to direct the organizational climate $\left(\mathrm{c}^{*}\right)$ through the management of his sensitivity (increase and reduction) to the incoming information from the global environment. An example of such an operation would be requiring the employees to learn English. If they do not speak English, they thereby reject all information that comes in English from the global environment (this acts as a kind of barrier

nerve ganglion cell axon; $D$, spinal nerve ganglion; $D^{\prime}$, skin; $d$, spinal nerve ganglion cell dendrite; e, sensory axon bifurcation branch; $f$, somatosensory brainstem relay; $g$, brainstem somatosensory > cortex axon terminals.

(A) Model developed using dialectic hermeneutic system of interpretation together with empirical research data from Human Resource Assessment Impact to Organization Climate: Case of Lithuanian Public Sector Organizations study and from Network Model of Human Resource Evaluation and Organizational Climate Interaction Phenomenon study. 
for incoming information); if they speak English the decision-making process starts (act as the spinal cord (B) in the human reflex arc $(\mathrm{S}))$ and the organizational climate $\left(\mathrm{c}^{*}\right)$ together with human resource assessment $\left(b^{*}\right)$, and internationalization level $\left(\mathrm{D}^{*}, \mathrm{~d}^{*}\right)$ starts acting as an unconditional response of human resources $\left(\mathrm{P}^{*} 1\right)$.

The inclusion of the management level of human resources ( $\left.f^{*}\right)$ and the managerial decisions $\left(A^{*}\right)$ to this process enabled the study to define the conditional response of human resources $\left(\mathrm{P}^{* 2}\right)$, which explains how organizations make decisions that require consideration. In this model, the unconditional response of human resources $\left(\mathrm{P}^{*} 1\right)$ can be related to the emotional response and the conditional response of human resources $(\mathrm{P} * 2)$ to the deliberate response.

In the model, the sequence of the response $\left(\mathrm{a}^{*}\right)$, Human resource assessment $\left(b^{*}\right)$, and effector $\left(C^{*}\right)$ reflect the condition of the motor-response $(\mathrm{P} * 3)$ that reflects the processes which are used in delivering the competitive response.

Table 1

Similarity modeling between the Histology of Neural Centers and an Organization's HR Communication with the External Environment Based on Analogical Reasoning

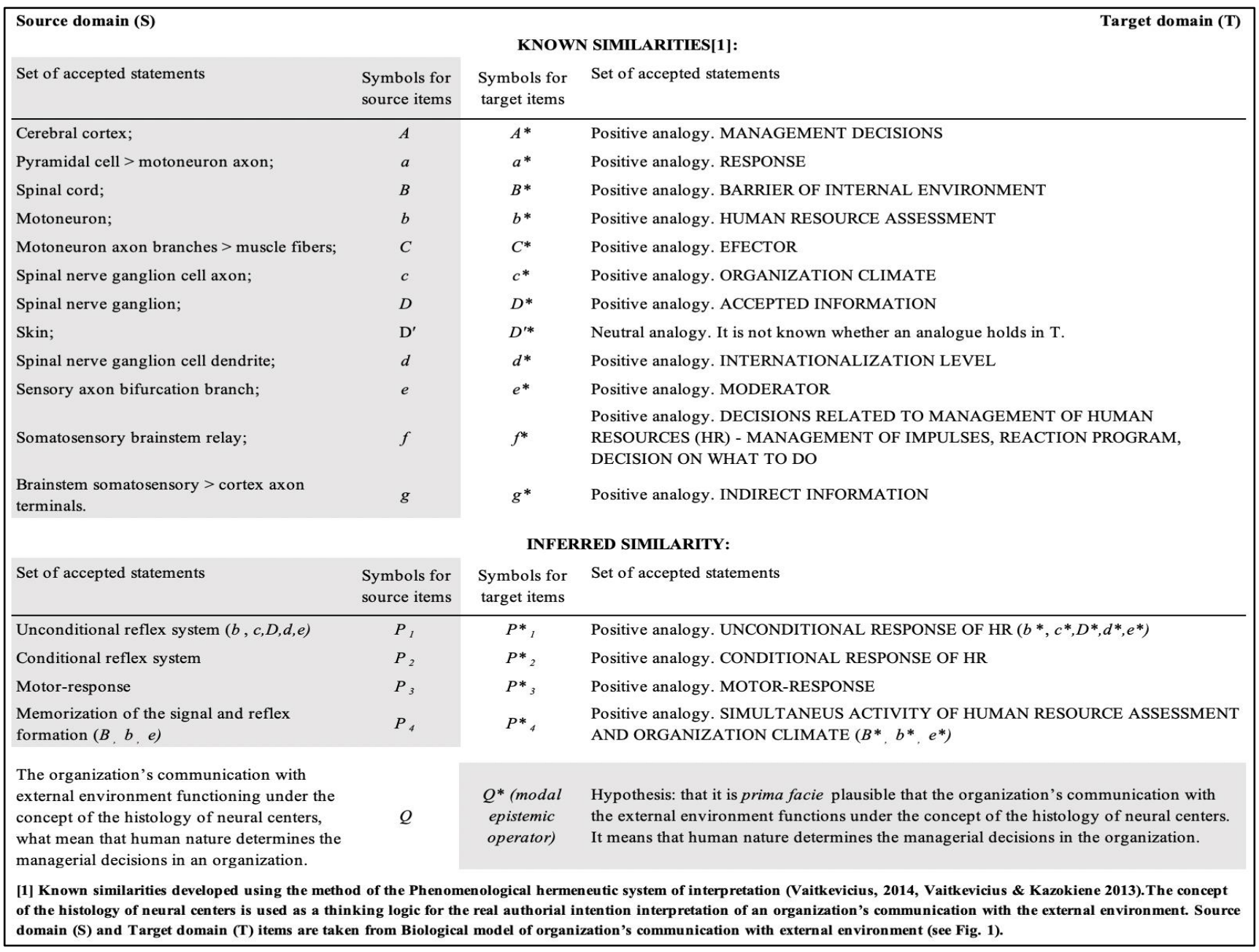

In summary, it can be stated that with the help of the Reflexes model of an organization's communication with the external environment, information acceptance in the organization was described, and the mechanism of actions taken to accept or reject the information incoming from the global environment in the organization operating in terms of internationalization was revealed. This discovery allows for knowing the organization better and helps in studying its competitive capabilities and timely response to the incoming signals.

The model was used because there was a need for an explanation of how organizations react to known and unknown signals incoming from the global environment.
The model explains how the organization forms the reflexes needed for its timely response to environmental change.

The developed Reflexes model of an organization's human resources response to the signals from the global environment explains how an organization receives external signals, reacts to them, and how barriers within the internal environment - distorting the signals sent from the global environment and decreasing the organization's response are formed inside of it. These barriers are important because of their significant role for the organization's conditional and unconditional reflexes development that possibly are responsible for timely response of organization to the influence that comes from external environment. 


\section{Discusion and Conclusions}

Similarity modeling between the histology of neural centers and an organization's HR communication with the external environment based on Analogical Reasoning explored that organizations like the humans has their own reflexes.

The developed model will further help in studying the processes inside the organization which help them to achieve greater competitiveness by developing unconditional reflexes and by the optimization of the conditional reflex structure. This possibly may lead to the development of new methods for an organization's management and decision-making process control.

Therefore, the COVID-19 situation shows the importance of development of organizational reflexes because it helps an organization to adopt to the global changes and survive and stay focused then changes happen.
More in-depth analysis of development of organizational reflexes is not presented in this paper, but hypothetically the similarity between the Histology of Neural Centers and an Organization's HR Communication with the External Environment led to presupposition that in the organization the reflexes can be a part of company's defensive and adaptation system. That mean, that global change called by COVID-19 crisis could be the best case for future study of the development and operation of organizational reflexes.

The finding that the reflexes of organizations like the human's reflexes are responsible for timely response and decision-making process management opens the possibility to study the organization's capability to reduce timely response to the signals incoming from the outer environment. Hypothetically can be stated that the less time organization need for decision making, the grater its competitiveness.

\section{References}

Akbar, K. S., Shah, M., \& Shah, L. H. (2019). Impact of organizational climate on occupational stress of teachers' working in public sector universities of Khyber Pakhtunkhwa. Dialogue, 14 (3), 30-37.

Allpsychologycareers (2016). What is Experimental Neuropsychology? Retrieved February 01, 2016, from Website: http://www.allpsychologycareers.com/topics/experimental-neuropsychology.html

Alon, I., Anderson, J., Munim, Z. H., \& Ho, A. (2018). A review of the internationalization of Chinese enterprises. Asia Pacific Journal of Management, 35 (3), 573-605. https://doi.org/10.1007/s10490-018-9597-5

Andersson, S., \& Sundermeier, J. (2019). Firms' use of organizational, personal, and intermediary networks to gain access to resources for internationalization. Thunderbird International Business Review, 61 (4), 609-621. https://doi.org/10. $\underline{1002 / \text { tie. } 22043}$

Arvey, R. D., \& Zhang, Z. (2015). Biological factors in organizational behavior and I / O psychology: an introduction to the special section. Applied Psychology: An International Review, 64 (2), 281-285. https://doi.org/10.1111/apps.12044

Babinska, D. (2013). The role knowledge in the internationalization process of firms - a review of selected research literature. Journal of Economics \& Management, 14, 9-20.

Barney, J. B., \& Felin, T. (2013). What are microfoundations? Academy of Management Executive, 27 (2), $138-155$. https://doi.org/10.5465/amp.2012.0107

Barrena-Martinez, J., Lopez-Fernandez, M., \& Romero-Fernandez, P. M. (2019). The link between socially responsible human resource management and intellectual capital. Corporate Social Responsibility \& Environmental Management, 26 (1), 71-81. https://doi.org/10.1002/csr.1658

Berberoglu, A. (2018). Impact of organizational climate on organizational commitment and perceived organizational performance: Empirical evidence from public hospitals. BMC Health Services Research, 18 (1), 399, 1-9. https://doi.org/10.1186/s12913-018-3149-z

Berdjaev, N. [Бердяев, Н.] (2006). Экзистенциальная диалектика божественного и человеческого. Москва: Хранитель.

Brymer, R. A., Boss, D. S., Uhlenbruck, K., \& Bierman, L. (2020). Business source complete internationalization's effect on mobility and firms' employee-based resources. Academy of Management Perspectives, 34 (1), 114-134. https://doi.org/10.5465/amp.2016.0179

Chaudhary, R. (2019). Green human resource management and job pursuit intention: Examining the underlying processes. Corporate Social Responsibility \& Environmental Management, 26 (4), 929-937. https://doi.org/10.1002/csr.1732

Chen, J., Saarenketo, S., \& Puumalainen, K. (2016). Internationalization and value orientation of entrepreneurial venturesa Latin American perspective. Journal of International Entrepreneurship, 14 (1), 32-51. https://doi.org/10.1007/ s10843-016-0169-9

Dadelo, S., Turskis, Z., Zavadskas, E., K., \& Dadeliene, R. (2012). Multiple criteria assessment of elite security personal on the basis of ARAS and expert methods. Economic Computation \& Economic Cybernetics Studies \& Research, 46 (4), 65-87.

Davenport, T. H., Leibold, M., \& Voelpel, S. C. (2007). Strategic Management in the Innovation Economy: Strategic Approaches and Tools for Dynamic Innovation Capabilities. John Wiley \& Sons 
Palmira Papsiene, Sigitas Vaitkevicius, Jura Vladas Vaitkevicius. Modeling of Timely Response of Human Resources to ...

Diefenbach, T. (2013). Hierarchy and Organization: Toward a General Theory of Hierarchical Social Systems. UK, London: Routledge. https://doi.org/10.4324/9780203752937

Dreher J. C., \& Tremblay L. (2017) Decision Neuroscience: An Integrative Perspective. Ed.: Dreher J.C., Tremblay L. Institute of Cognitive Science (CNRS), Lyon, France. Elsevier.

Ellis, A. W., \& Young, A. W. (1995). Human cognitive neuropsychology: A textbook with readings. Hove, UK: Psychology Press.

Elrehail, H., Harazneh, I., Abuhjeeleh, M., Alzghoul, A., Alnajdawi, S., \& Ibrahim, H. M. H. (2020). Employee satisfaction, human resource management practices and competitive advantage. Accounting Horizons, 34 (2), 125-149. https://doi.org/10.1108/EJMBE-01-2019-0001

Fitzgerald, R., \& Rowley, C. (2016). Internationalization patterns and the evolution of multinational companies: comparing Japan, Korea, China and India. Asia Pacific Business Review, 22 (4), 523-533. https://doi.org/10.1080/1360 2381.2016.1168672

Fos, N. J. (1994). The biological analogy and the theory of the firm: Marshall and Monopolistic competition. Journal of Ecnomic, 28 (4), 1115-1136. https://doi.org/10.1080/00213624.1994.11505614

Gavin, H. (2018, February 5). Organized anarchies: 13 steps to building a "Learning organization". New England Journal of Higher Education. https://nebhe.org/journal/organized-anarchies-13-steps-to-building-a-learning-organization/

Gaviria-Rivera, J. I., \& Zapata, E. L. (2019). Transformational Leadership, Organizational Climate and Job Satisfaction in Work Teams. European Research Studies Journal, 22 (3), 68-82. https://doi.org/10.35808/ersj/1457

Godos-Diez, J.-L., Cabeza-Garcia, L., \& Fernandez-Gonzalez, C. (2018). Relationship between corporate social responsibility (CSR) and internationalisation strategies: A descriptive study in the Spanish context. Administrative Sciences, 8 (4), 57. https://doi.org/10.3390/admsci8040057

Gokalp, E., Demirors, O., \& Eren, P. E. (2020). Public personnel management process capability assessment. Public Personnel Management, 49 (1), 111-140. https://doi.org/10.1177/0091026019833412

Guest, E. D. (1987). Human resource management and industrial relations. Journal of Management Studies, 24 (5), 503521. https://doi.org/10.1111/j.1467-6486.1987.tb00460.x

Gunnigle, P., Lavelle, J., \& Monaghan, S. (2019). Multinational companies and human resource management in Ireland during recession: A retrospective from a highly globalized economy. Thunderbird International Business Review, 61 (3), 481-489. https://doi.org/10.1002/tie.21978

Han, J. H., Kang, S., Oh, I. S., Kehoe, R., \& Lepak, D. (2019). The goldilocks effect of strategic human resource management? Optimizing the benefits of a high-performance work system through the dual alignment of vertical and horizontal fit. Academy of Management Journal, 62 (5), 1388-1412. https://doi.org/10.5465/amj.2016.1187

Hu, W., \& Zhao, S. (2020). Strategic human management evaluation for marine enterprises. Journal of Coastal Research, 107, 57-60. https://doi.org/10.2112/JCR-SI107-015.1

Hudson, H. (2001). A Materialist Metaphysics of the Human Person. USA: Cornell University Press. https://doi.org/10.7591/9781501725715

Isoraite, M. (2011). Zmogiskieji istekliai - svarbiausias konkurencinio pranasumo saltinis, strategiskai valdant organizacija. Socialiniu mokslu studijos, 3(1), 31-58.

Jankowska, B., \& Gotz, M. (2017). Internationalization intensity of clusters and their impact on firm internationalization: the case of Poland. European Planning Studies, 25 (6), 958-977. https://doi.org/10.1080/09654313.2017.1296111

Jashary, A., \& Kutllovci, E. (2020). The impact of human resource management practices on organizational performance case study: Manufacturing enterprises in Kosovo. Business: Theory and Practice, 21 (1), 222-229. https://doi.org/10.3846/btp.2020.12001

Kalvionyte, A., \& Korsakiene, R. (2016). Intelektinio kapitalo itaka verslo internacionalizacijos procesams Lietuvos imonese. Science: Future of Lithuania, 8 (2), 149-158. https://doi.org/10.3846/mla.2016.895

Kazlauskaite, R., \& Buciuniene, I. (2008). The role of human resources and their management in the establishment of sustainable competitive advantage. Inzinerine Ekonomika-Engineering Economics (5), 78-84.

Kersiene, R. (2008). Konkurencingumo issaugojimo veiksniai globalizacijos salygomis. Ekonomika ir vadyba, 14, 819824.

Klinck, K., \& Swanepoel, S. (2019). A performance management model addressing human factors in the North West provincial administration. South African Journal of Human Resource Management, 17 (1), 1-17. https://doi.org/10.41 02/sajhrm.v17i0.1021

Li, Y., Wang, M., van Jaarsveld, D. D., Lee, G. K., \& Ma, D. G. (2018). From employee-experienced high-involvement work system to innovation: An emergence-based human resource management framework. Academy of Management Journal, 61 (5), 2000-2019. https://doi.org/10.5465/amj.2015.1101 
Milne, R. S. (1970). Mechanistic and organic models of public administration in developing countries, Administrative Science Quarterly, 15(1), 57-67. https://doi.org/10.2307/2391188

Morgan, G. (2006). Images of Organization. Thousand Oaks, CA: Sage Publications, Inc.

Naldoken, U., \& Tengilimoglu, D. (2017). A field study on determining the effects of organizational climate in terms of social interaction on knowledge management at health organizations. Journal of Economics \& Management, 29 (3), 75-101. https://doi.org/10.22367/jem.2017.29.05

Nasreen, A., Varshney, P., \& Waseem, C. (2019). Organizational climate In NBFC: Implications on employee engagement. Amity Global Business Review, 9, 7-14.

Neuronal connections. [Neuronu jungtis (sinapse)]. (2007). Retrieved April 02, 2014, from Website: http://www.technologijos.lt/n/mokslas/zmogus_ir_medicina/straipsnis?name=straipsnis-4026

Newman, A., Miao, Q., Hofman, P. S., \& Zhu, C. J. (2016). The impact of socially responsible human resource management on employees' organizational citizenship behaviour: the mediating role of organizational identification. International Journal of Human Resource Management, 27 (4), 440-455. https://doi.org/10.1080/09585192.2015.1042895

Niman, N. B. (1994). 14-The role of biological analogies in the theory of the firm, 360-383. Edited by Mirowski, P. Natural Images in Economic Thought "Markets Read in Tooth \& Claw". Cambridge University Press. https://doi.org/10.1017/ CBO9780511572128.014

Pandey, A. A., \& Chandel, S. (2013). Human resource assessment of a district hospital applying WISN method: Role of laboratory technicians. International Journal of Medicine \& Public Health, 3 (4), 267-270. https://doi.org/10.4103/ 2230-8598.123459

Penrose, E. (1952). Biological analogies in the theory of the firm. American Economic Review, 42, 804-819.

Phua, F. T. T. (2018). The role of organizational climate in socially embedding construction firms' sustainability goals. Construction Management \& Economics, 36 (7), 409-421. https://doi.org/10.1080/01446193.2018.1424348

Polat, D. D., \& Iskender, M. (2018). Exploring teachers' resilience in relation to job satisfaction, burnout, organizational commitment and perception of organizational climate. International Journal of Psychology and Educational Studies, 5 (3), 1-13. https://doi.org/10.17220/ijpes.2018.03.001

Popa, I. L., \& Demyen, S. (2012). Indicators of effective human resource assessment in management. Annals of Eftimie Murgu University Resita, Fascicle II, Economic Studies, 408-412.

Pozveh, A. Z., \& Karimi, F. (2016). Relationship between organizational climate and the organizational silence of administrative staff in education department. International Education Studies, 9 (6), 120-129. https://doi.org/10. 5539/ies.v9n6p120

Riego de Dios, E. E. (2020). Supervisory relationship, organizational climate and satisfaction of employees in a local community college. International Journal Academic Management Science Research, 4 (2), 164-170.

Rodjam, C., Thanasrisuebwong, A., Suphuan, T., \& Charoenboon, P. (2020). Effect of human resource management practices on employee performance mediating by employee job satisfaction. Systematic Reviews in Pharmacy, 11 (3), 37-47. https://doi.org/10.5530/srp.2020.3.05

Roscoe, S., Subramanian, N., Jabbour, C. J. C., \& Chong, T. (2019). Green human resource management and the enablers of green organisational culture: Enhancing a firm's environmental performance for sustainable development. Business Strategy \& the Environment, 28 (5), 737-749. https://doi.org/10.1002/bse.2277

Roscoe, S., Subramanian, N., Jabbour, C. J. C., \& Chong, T. (2019). Green human resource management and the enablers of green organisational culture: Enhancing a firm's environmental performance for sustainable development. Business Strategy \& the Environment, 28 (5), 737-749. https://doi.org/10.1002/bse.2277

Sadowska, B., \& Lulek, A. (2020). Management of manufacturing resources in an enterprise on the example of human resources. Acta Scientiarum Polonorum. Oeconomia, 19 (2), 61-70. https://doi.org/10.22630/ASPE.2020.19.2.18

Seilius, A., \& Simanskiene, L. (2006). Verslo organizaciju valdymas globalizacijos salygomis: teorinis poziuris. Verslas: teorija ir praktika, 4(7), 213-221. https://doi.org/10.3846/btp.2006.26

Shah, M. (2019). Green human resource management: Development of a valid measurement scale. Business Strategy and the Environment, 28 (5), 771-785. https://doi.org/10.1002/bse.2279

Stanford Encyclopedia of Philosophy (2015. Jan.15). Mereology. Stanford Encyclopedia of Philosophy / First published Tue May 13, 2003; substantive revision Thu Jan 15, 2015. Retrieved February 08, 2016, from Website: http://plato.stanford.edu/entries/mereology/

Stanford Encyclopedia of Philosophy. Existentialism. Retrieved February 01, 2016, from Website: https://plato.stanford.edu/entries/existentialism/ 
Palmira Papsiene, Sigitas Vaitkevicius, Jura Vladas Vaitkevicius. Modeling of Timely Response of Human Resources to ...

Suseno, Y., \& Pinnington, A. H. (2018). Building social capital and human capital for internationalization: The role of network ties and knowledge resources. Asia Pacific Journal of Management, 35 (4), 1081-1106. https://doi.org/10. 1007/s10490-017-9541-0

Swanson, L. W., \& Bota, M. (2010). Foundational model of nervous system structural connectivity with a schema for wiring diagrams, connectome, and basic plan architecture. Proceedings of the National Academy of Sciences of the United of America, 107, 20610-20617. https://doi.org/10.1073/pnas.1015128107

Tang, G, Wei, L. Q., Snape, E., \& Ng, Y. C. (2015). How effective human resource management promotes corporate entrepreneurship: evidence from China. International Journal of Human Resource Management, 26 (12), $1586-1601$. https://doi.org/10.1080/09585192.2014.953973

Udehn, L. (2002). The Changing face of methodological individualism. Annual Review of Sociology, $28,479-507$. https://doi.org/10.1146/annurev.soc.28.110601.140938

Vahlne, J.-E., \& Bhatti, W. A. (2019). Relationship development: A micro-foundation for the internationalization process of the multinational business enterprise. Management International Review, 59 (2), 203-228. https://doi.org/10.1007/s11575-018-0373-z

Vaitkevicius, S. (2013). Rethinking the applicability of hermeneutic systems for coding and statistical analysis of authorial intentions in economics. Inzinerine Ekonomika-Enginering Economics, 24 (5), 415-423. https://doi.org/10. 5755/j01.ee.24.5.4705

Vasantha, R. L., \& Kennedy, H. (2017). The role of business sustainability in human resource management: A study on Indian manufacturing companies. South East Asian Journal of Management, 11 (1), 70-85. https://doi.org/10.21 $\underline{002 / \text { seam.v11i1.7739 }}$

Walker, L. M., Hampton, A., \& Robinson, J. W. (2014). Assessment of relational intimacy: factor analysis of the personal assessment of intimacy in relationships questionnaire. Psycho-Oncology, 23 (3), 346-349. https://doi.org/10.10 02/pon.3416

Webber, J. (2011). Reading Sartre: on Phenomenology and Existentialism. UK: Routledge. https://doi.org/10.4324/97802038 $\underline{44144}$

Wilson, E. O. (1975). Sociobiology: The new synthesis. Cambridge, MA: Belknap Press.

Yang, M. X., Li, J., Yu, I. Y., Zeng, K. J., \& Sun, J-M. (James). (2019). Environmentally sustainable or economically sustainable? The effect of Chinese manufacturing firms' corporate sustainable strategy on their green performances. Business Strategy and the Environment, 28 (6), 989-997. https://doi.org/10.1002/bse.2296

Youndt, M. A., Snell, S. A., Dean, Jr. J. W., \& Lepak, D. P. (1996). Human resource management, manufacturing strategy, and firm performance. The Academy of Management Journal, 39 (4), 836-866. https://doi.org/10.2307/256714

\section{Authors' biographies}

Sigitas Vaitkevičius is a research professor at the Vytautas Magnus University, Lithuania. His main research areas include organizational behavior, strategic management, and the research methodology. He is a member of Lithuanian Educational Board and he is an owner of business company. He has published his works in various international conferences and research papers.

Palmira Papšienė is a junior researcher at Agriculture Academy of Vytautas Magnus University, Lithuania. Her main research areas include organizational behavior, human resources management, and marketing. Her works have been published in various national and international conferences and research papers.

Jura Vladas Vaitkevičius is a research professor at Vytautas Magnus University and an associated professor at the department of Health and Social Welfare Studies, Siauliai University, Lithuania. His main research areas include public health, human anatomy, physiology and hygiene. He has published his works in various national and international conferences and research papers.

The article has been reviewed.

Received in September 2019; accepted in February 2021.

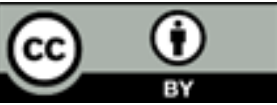

This article is an Open Access article distributed under the terms and conditions of the Creative Commons Attribution 4.0 (CC BY 4.0) License (http://creativecommons.org/licenses/by/4.0/). 